\title{
DURANTE AS ELEIÇÕES, PENSE BEM PARA QUEM VAI ENTREGAR A CHAVE DO COFRE
}

Coluna publicada em 26.8.2014: <http://www.conjur.com.br/2014-ago-26/ eleicoes-pense-bem-quem-entregar-chave-cofre $>$

"No dinheiro está o princípio vital do organismo político; o tesouro é o coração do Estado; a gerência das finanças envolve a supremacia sobre a ação do governo" (Rui Barbosa).

As sábias palavras de um dos maiores gênios brasileiros continuam mais atuais do que nunca. Poucas palavras que muito explicam, como veremos.

A corrida (ou guerra?) eleitoral já começou. Vê-se, sem sombra de dúvida, que os cargos mais disputados são os de Chefe do Poder Executivo - no caso desta eleição, Governadores de Estado e Presidente da República.

Em nosso país, cuja Constituição consagra o Estado Democrático de Direito (art. $1^{\circ}$ ), com separação de poderes (art. $2^{\circ}$ ), isso não deixa de ser curioso, pois o Poder Legislativo é o principal responsável pela elaboração e aprovação das leis a que todos estamos sujeitos. Deveria, pois, ser o mais "importante", que tem mais "poder" e, consequentemente, o mais cobiçado.

Mas não é o que ocorre.

Observe que, na prática, quem tem mais poder é o Chefe do Poder Executivo. É isso que justifica serem eles mais conhecidos e esses cargos mais cobiçados e objeto de desejo da grande maioria dos políticos. Veja você mesmo, caro leitor. Pergunto-lhe: você sabe quem é o Presidente (ou seria Presidenta? Solicito ajuda dos gramáticos!) da República? O Governador do Estado? O Prefeito do Município? A resposta é em regra positiva e segura. E o Presidente do Congresso Nacional? Da

1 No sentido coloquial do termo, sem entrar em discussōes mais profundas sobre o exato conteúdo e significado da expressão, uma vez não ser o propósito deste breve texto. 
Assembleia Legislativa? Da Câmara Municipal? Quem é o Presidente do Supremo Tribunal Federal? Dos demais Tribunais Superiores? E do Tribunal de Justiça? Essas últimas são mais difíceis, não é mesmo? As respostas nem sempre são certas e, no mais das vezes, com hesitações.

E porque isso ocorre? De onde vem esse "poder maior", essa supremacia, do Poder Executivo?

A resposta, embora não seja tão difícil, é pouco conhecida. E quem nos dá é o Direito Financeiro. Rui Barbosa nos indica o caminho para chegar a ela.

As leis orçamentárias, que definem as receitas e despesas, são, como já tenho repetido, fazendo coro à nossa Suprema Corte, as mais importantes do ordenamento jurídico depois da Constituição. ${ }^{2}$

E, em todo o processo que envolve as leis orçamentárias, desde sua elaboração, passando pela execução e fiscalização, no chamado ciclo orçamentário, o Poder Executivo tem papel destacado. Não deveria ser o principal, uma vez que em nosso Estado Democrático de Direito "todo o poder emana do povo, que o exerce por meio de representantes" (CF, art. $1^{\circ}$ e parágrafo único), que tem (ou deveria ter...) no Poder Legislativo seu mandatário mais fiel, como bem colocou o ministro Luiz Fux: "Se, por certo, não só o Poder Legislativo busca raízes de legitimidade no povo, já que, como afirma a Constituição Federal de 1988, é deste último que todo o poder emana ( $\mathrm{CF}$, art. $1^{\circ}$, parágrafo único), nem por isso se pode ignorar que cabe ao Parlamento, na lógica que perpassa a tripartição dos poderes, a primazia no papel de caixa de ressonância da vontade popular, derivada (i) da forma de provimento de seus cargos pela via do batismo democrático e, simultaneamente, (ii) da composição plúrima a espelhar os diversos segmentos da sociedade". ${ }^{3}$

Mas a realidade, nesse caso, não é muito coerente com a teoria, como se verá.

A importância das leis orçamentárias reflete-se no ciclo orçamentário, em que se observa haver extremo cuidado em dividir as diversas fases entre os poderes Executivo e Legislativo, atribuindo-se competências a ambos, de modo a deixar evidente a presença do sistema de "freios e contrapesos". Em síntese, o Poder Executivo tem a iniciativa da lei orçamentária, que é aprovada pelo Poder Legislativo, cabendo ao Executivo conduzir a sua execução, que o Legislativo fiscalizará.

Muitos são os poderes do Executivo na primeira fase do ciclo orçamentário, a começar pela prerrogativa de apresentar a proposta de orçamento, conforme

2 Ministro Carlos Ayres Britto, STF, ADI-MC 4.048-1/DF, j. 14.5.2008, p. 92 dos autos.

3 STF, ADI-MC 4.663. 
expressamente dispõe o artigo 165 da Constituição, o que já é por demais significativo, tendo em vista as limitaçôes do Poder Legislativo em propor emendas ao projeto $\left(\mathrm{CF}\right.$, art. $\left.166, \$ 3^{\circ}\right)$.

Limitações estas que, na prática, são muito maiores do que prevê nossa Constituição. Isso porque já se institucionalizou, na generalidade dos entes que compõem nossa federação, a prática de definir previamente uma "cota" para as emendas do Poder Legislativo, ${ }^{4}$ sujeitando nossos parlamentares a propor alterações no montante estabelecido (em geral, valores que não atingem $1 \%$ do orçamento total), que não alteram de forma relevante o orçamento - o que o torna, de fato, uma lei quase integralmente de autoria do Poder Executivo.

O Poder Legislativo, contudo, é quem tem a palavra final em matéria de finanças públicas: cabe a ele aprovar as leis orçamentárias.

Mas a supremacia do Poder Executivo aparece de forma mais evidente na fase de execução orçamentária, na qual tem papel predominante e fica clara sua função de gestor das finanças públicas.

A lei orçamentária, como toda e qualquer lei, existe para ser cumprida. Tem, no entanto, algumas peculiaridades que permitem reconhecer legítimo e necessário sujeitar-se a algum grau de flexibilidade em sua execução. Elaborada com base em previsões de arrecadação, que vão estabelecer o montante de receitas e consequente limite das despesas, vê-se haver inúmeros fatos futuros e incertos que impedem seja a lei executada um espelho daquela que foi aprovada.

Flexibilidade esta que, embora necessária, deve ter sua extensão reduzida ao mínimo, restringindo-se as possibilidades de alteração do que foi aprovado. Mas não é o que acontece.

Generalizou-se a prática de estabelecer autorizações prévias para que o Executivo abra créditos suplementares (Lei 4.320, de 1964, art. 7º, I), as chamadas "margens de remanejamento", de tal forma exageradas, que dispensam toda e qualquer necessidade de lei para aprovar referidos créditos responsáveis por alterar o orçamento. Uma verdadeira delegação do Poder Legislativo ao Poder Executivo para conduzir a execução orçamentária da forma que lhe aprouver, aumentando, diminuindo, remanejando e transferindo recursos, de modo a descaracterizar as dotações que inicialmente constavam das leis orçamentárias.

O contingenciamento, instrumento destinado a adequar o fluxo da atividade financeira do Estado, compatibilizando o ingresso com a saída de recursos, tem

4 Como já expus na coluna Emendas ao orçamento e o desequilíbrio de Poderes, publicada em 3 de julho de 2012. 
sido utilizado de maneira ilegítima pelo Poder Executivo, limitando o empenho para postergar os gastos com a finalidade de "criar dificuldades para vender facilidades", como já exposto em coluna anterior.

Transferências voluntárias, importante mecanismo para adequar a partilha de recursos e minimizar distorções na distribuição das receitas em nosso sistema federativo, têm sido utilizadas pelos Poderes Executivos da União e dos Estados não como instrumentos de um federalismo cooperativo, mas sim de subordinação política dos entes subnacionais, criando relaçôes de dependência que ferem o princípio federativo. ${ }^{6}$

São muitas as distorçôes, vários os desvios, que distanciam a teoria da realidade e mostram que, em matéria orçamentária, o sistema de "freios e contrapesos" não está funcionando como deveria. O Poder Executivo, em nosso país, sem que a Constituição autorizasse, se apossou do tesouro, o "coração do Estado", controlando o dinheiro público, "princípio vital do organismo político", o que lhe tem dado a supremacia das ações governamentais, para usar as precisas palavras de Rui Barbosa.

As eleições se aproximam. É hora de pensar bem em quem votar. Todos querem pegar a "chave do cofre". Fique atento para quem vai entregá-la.

5 Hora é de "apertar o cinto" e contingenciar gastos, publicada em 11 de março de 2014.

6 Assunto já abordado na coluna Transferências voluntárias geram desequilíbrio federativo, publicada em 28 de agosto de 2012. 